\title{
Geological and Geotourism Study of Iran Geology Natural Museum, Hormoz Island
}

\author{
Abdollah Yazdi 1*, Mohammad Ali Arian², Mahmoud M. Rezapour Tabari ${ }^{3}$ \\ ${ }^{1}$ Department of Geology, Kahnooj Branch, Islamic Azad University, Kerman, Iran \\ ${ }^{2}$ Department of Geology, North Tehran Branch, Islamic Azad University, Tehran, Iran \\ ${ }^{3}$ Department of Engineering, Shahrekord University, Shahrekord, Iran \\ Email: ${ }^{*}$ Yazdi mt@yahoo.com
}

Received 28 July 2014; revised 14 August 2014; accepted 19 August 2014

Copyright (C) 2014 by authors and Scientific Research Publishing Inc.

This work is licensed under the Creative Commons Attribution International License (CC BY).

http://creativecommons.org/licenses/by/4.0/

c) (i) Open Access

\begin{abstract}
Iran is a country that benefits from nice nature, diverse continent, areas full of unique geological phenomena. Thus, it is necessary to study these attractions for better recognition of them. In this regard, Hormoz Island with valuable geoheritage, biodiversity, cultural, historical and political diversity is very important. The accumulation of these attractions and its being located in Persian Gulf strategic area made it of considerable significance in national and international communities. Hormoz Island is a spherical salt dome which is located in Hormoz strait. This Island is composed of evaporites, igneous rocks and sedimentary rocks, and sediments mainly belong to Mishan and Aghajari formations and salt, gypsum and, to a lesser extent, limestone evaporites. In sedimentary formations of Hormoz, Aouthigenic minerals such as Pyrite, Dolomite, quartz, Anhydrite, gypsum and halite are frequently seen. Mineralization of volcanic leads to formation of high temperature minerals, such as oligiste, pyroxene, amphibole and low temperature and hydrothermal minerals such as Pyrite, quartz... in the tracks of igneous rocks. This unique geodiversity in rocks and mineral which made various colors in Hormoz Island made it a mineraogical reservoir. Beside considerable mineralogical attractions, there are other potentials like ochre mine, coral reefs, rock seashore, sea caves, salt caves, plant cover and wild life which have added to various tourism capabilities of this Island and made it a unique place in the world. This paper studies Hormoz Island in terms of geological features and geotourism potentials.
\end{abstract}

\section{Keywords}

Salt dome, Geology, Geodiversity, Geotourism, Hormoz Island, Iran

"Corresponding author. 


\section{Introduction}

In recent years, tourism industry has become one of the main poles of development from various respects, especially economic source. It is such that most authorities believe that tourism will become dominant industry in near future and will have various socioeconomic effects (Bayati Khatibi, 2010) [1]. Due to job creation and relatively rapid profiting characteristic, tourism is a proper ground for foreign investment and can accelerate tourism development, promote its economic criteria and bring out new ideas, technologies and markets (Papeli Yazdi, 2011) [2]. Geotourism, as a subcategory of tourism, is considered one of the new methods in providing tourism attraction (Servati, 2008) [3] and has allocated a main part of tourism studies to itself. Iran has a nice nature, diverse continent and areas full of unique geological phenomenon so that it seems necessary to investigate these attractions for their better cognition and geotourism development (Yazdi, 2012) [4].

Iran is one of the few countries of the world with beautiful natural and geological phenomenon due to its unique and excellent geographical condition. In this regard, Hormoz Island has become geological paradise due to certain geological condition and unique diversity of minerals and rocks and attracted many geotourists. This spherical island has been located in Persian Gulf' entrance in $56^{\circ} 25^{\prime}$ to $56^{\circ} 30^{\prime}$ east longitude and $27^{\circ} 2^{\prime}$ to $27^{\circ} 6^{\prime}$ north altitude. Its long diameter is maximumly $9 \mathrm{~km}$, its short diameter is almost $5.5 \mathrm{~km}$, and it covers an area about $41 \mathrm{~km}$ (Figure 1). This Island is an adult salt dome and its morphological, mineralogical and lithological diversity is significant. Besides geological attractions, this area benefits from historical attractions like Portuguese castle and natural attractions such as alga seashore, wildlife, etc. which will be investigated in this paper.

\section{Methodology}

This research is practical and developmental and the methodology used in it is descriptive-analytical. Based on this, library-documentary studies, interpretation and analysis of satellite images, various field studies and direct observation of phenomenon have been used.

\section{Geotourism}

Geotourism is a relatively new concept in tourism industry which has considerable growth in recent decade. Geotourism has a certain definition with geological tourism at its centre (Newsome \& Dowling, 2006) [5] and deals with the investigation of related forms and consequences to earth, geomorphologic and geological phenomena. According to Gates (2006) [6], geotourism means “tourism in geological outlooks”. Geotourism, according to Dowling \& Newsome (2006) [7], deals with geology, geomorphology, natural outlooks and the forms of earth surface, layers with fossil, rocks and minerals with emphasis on the creating processes. Furthermore, it can be argued that geotourism is informed and responsible tourism in nature with the aim of looking at recognition of geological phenomena and processes and learning their formation and revolution (Amrikazemi, 2009) [8]. According to the above definitions, geotourism is not only is new part of tourism market, it is a principal guidance to help maintaining nature and sustainable development, which is compatible with the economic equilibrium, social condition and ecology and complements them.

\section{Geology of Hormoz Island}

This Island is one of the biggest and most famous salt domes of Persian Gulf whose formation has begun from

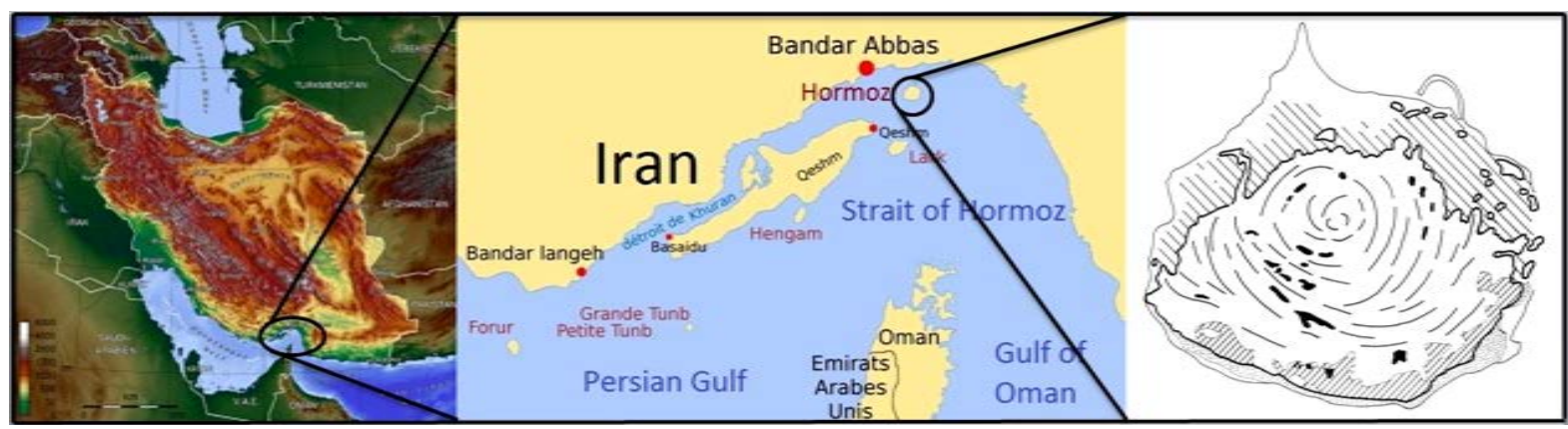

Figure 1. The location of Hormoz Island in Iran. 
late Precambrian and come out of water about 50,000 years ago. Hormoz Island is almost structurally concentric with evaporites, igneous rocks and sedimentary rocks layers. Bland Ford in 1872 called the collection of igneous, metamorphic and evaporites rocks of this area as Hormoz Series.

According to Elyasi et al. (1975) [9], this Island is composed of evaporites rocks, ferroginous formations and Miocene-Pliocene sediments (Figure 2). Beside evaporites, sedimentary rocks and igneous are can be find which has been previosly called Hormoz formation. Stocklin [10] in his study from 1961 to 1968 concluded that expression Hormoz series is true for underlying salt layers and gypsum and sandy rocks and limestone with fossil can be separated and limit the expansion of evaporites in late Precambrian in northern-southern extent of wide area which reaches Oman-Naiband fracture from east and Qatar-Kazeron fracture from west (Stocklin, 1972) [10]. In overall, Hormoz series collection can be attributed to a row of evaporites, igneous and rarely metamorphic rocks which have been deposited after late Precambrian. These rocks began with a complete cycle with dark and usually dolomite carbonate rocks and sediment on chalk, salt and shale. Concerning the similarity of Hormoz series fossils and fossils on lower part of Valdai series in Russia platform and late part of Precambrian in Australia, Hormoz series can be considered as belonging to late Precambrian.

Various magma activities in Magma Island are seen in form of extrusive and intrusive. Igneous events happened in two phase, the first one includes analysed basalt and diabase and the second one includes rhyolite, rhyodacite and trachyte which respectively belong to Permian and Triassic. The mentioned rocks, except rhyolite (Figure 3) which is somehow intact, are mainly decomposed.

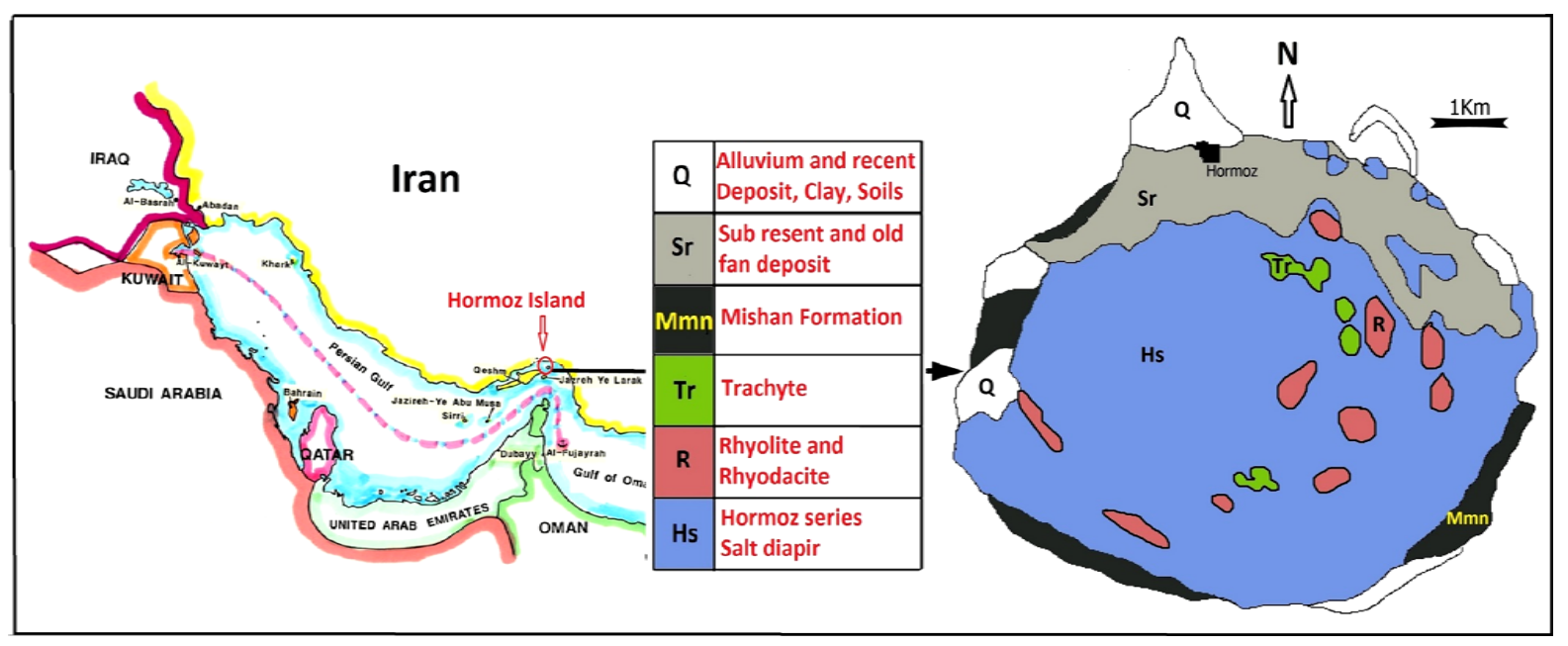

Figure 2. Geology map of Hormoz Island by corrections (Elyasi et al., 1975) [9].

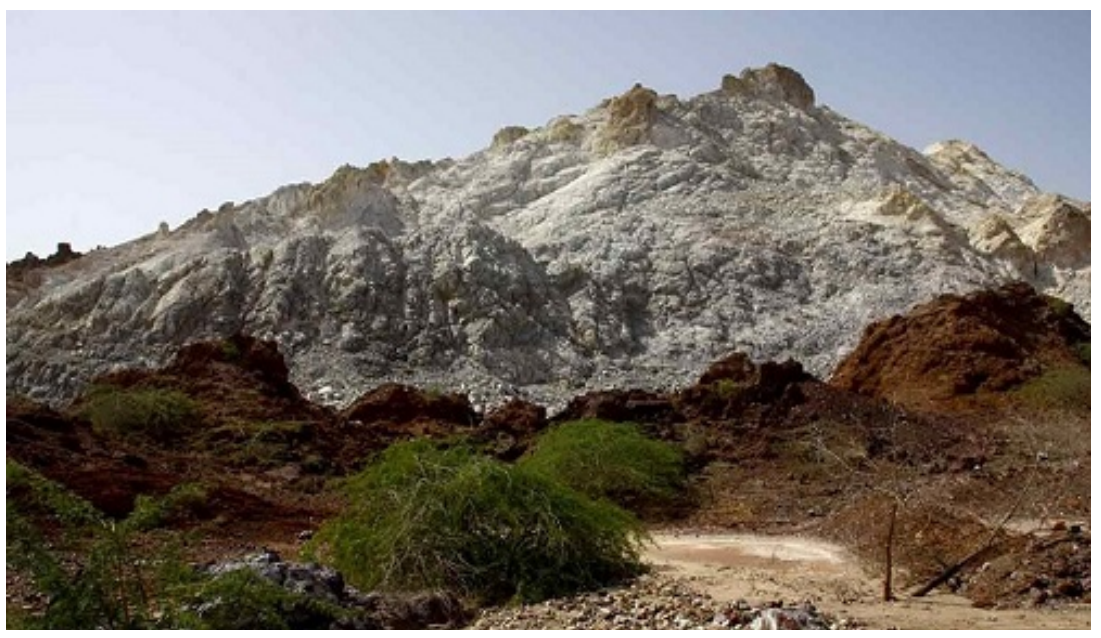

Figure 3. An overview of Trakyt-Riolite mass of Hormoz Island. 


\section{Hormoz Slat Dome}

In southern Zagros area, there is about 130 salt domes which erosion has created beautiful perspectives in them (Figure 4) such as salt cave in these salt domes. In lower layers of Persian Gulf area, there is a thick bed of salt in 4 - $10 \mathrm{~km}$ depth which due to special weight less than lateral rocks and the weight pressure of the upper layers, penetrated in higher layers and reached surface and created various domes. This salt movement might happen in faults through sedimentary layers... The width of most salt domes is about 1 to $10 \mathrm{~km}$ and their big dome-like mountains are usually salt lump however, their surface is usually covered by red soils.

The main soil of its covering rock with several meter thickness is in fact the residual of insolvable materials from the main salt beds. The dominant soil of this bed is clay and silt with usually more than $50 \%$ plaster-rock. The red colour is up to $15 \%$ related to iron oxide that is usually in form of hematite. Some black salt domes are frequently seen. The lump values for salt domes in southern Zagros are usually 2 to $6 \mathrm{~mm}$. Although it seems that in some sample, $15 \mathrm{~mm}$ growth has happened (Waltham, 2008) [11].

Hormoz salt dome has come out of water about 50,000 years ago and due to severity of salt tectonic movements, Neogenes sedimentary layers reached 75-degree slope. Raining has been able to be effective in salt domes in creation of cavities and salt caves as can be seem in seashore salt domes "Namakdan and Hormoz" in Qeshm and Hormoz Islands which have been identified and drawn by geologists from Czech (Figure 5).

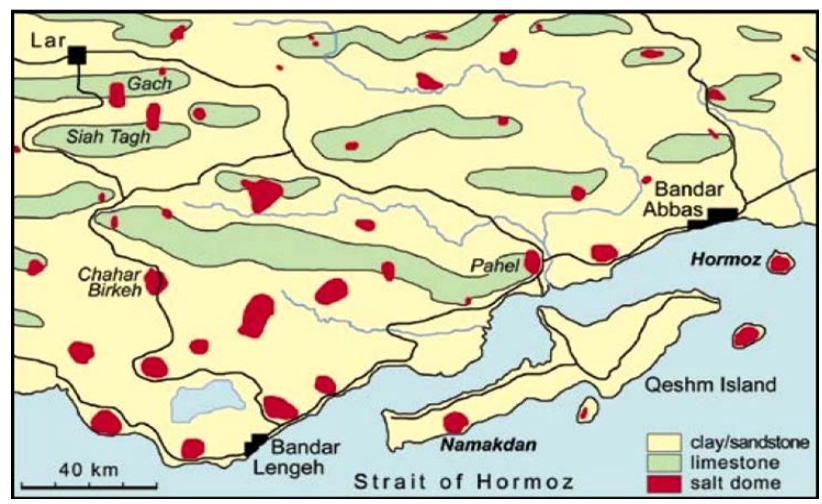

Figure 4. The situation of salt domes of south Zagros and Persian Gulf.

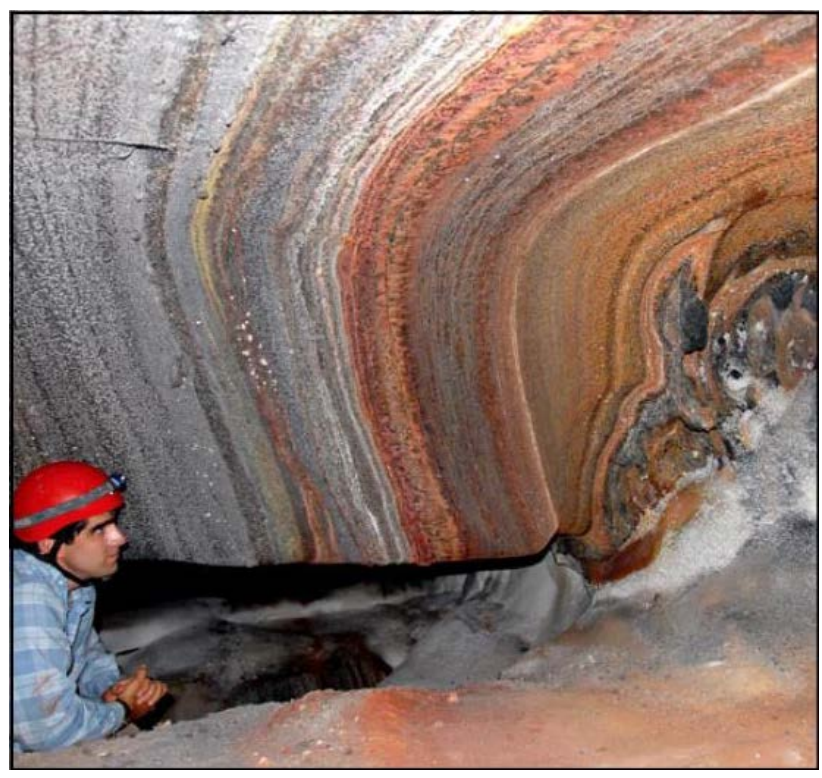

Figure 5. Layering of salt and iron oxide in roof of salt cave of Hormoz salt dome. 


\section{Geological and Geotourism Attraction of Hormoz Island}

In addition to attractive biological outlooks of Hormoz Island, the geological attractions and perspectives of this Island is very interesting and extraordinary. Eye-catching attractions of Hormoz are influenced by diversity of rocks and minerals which became visible due to protrusion of Hormoz salt done. The diversity of soil colour, rocks and minerals has made this Island a colourful natural tableau and provided a paradise for researchers of geology. In overall, the most important geotourism attraction of Hormoz Island can be presented as following.

\subsection{Hormoz Seashores}

- Southern and eastern seashores of Hormoz are mostly constituted from low, high and rocky beaches. In these areas, mostly fossilized lime layers are at the surface and on the less-strength layers and are relatively resistive against erosion of waves. These layers cover non-resistive units like cover rock. Various small and large cavities have been created in lower parts of rocks due to collision of waves and erosion. These dents have been formed at the bottom of rocks and would become larger over time (Figure 6 \& Figure 7).

- Another part of Island seashore near to ocher (red soil) mine is known as red seashore. Due to collision of seawater and this soil which has high iron oxide, the colour of this beach turns red and creates a beautiful scene (Figure 8).

- Other parts of Hormoz Island are known as colourful beaches. Each area of its colourful mountain represents a beautiful and extraordinary beach and has unique diversity (Figure 9).

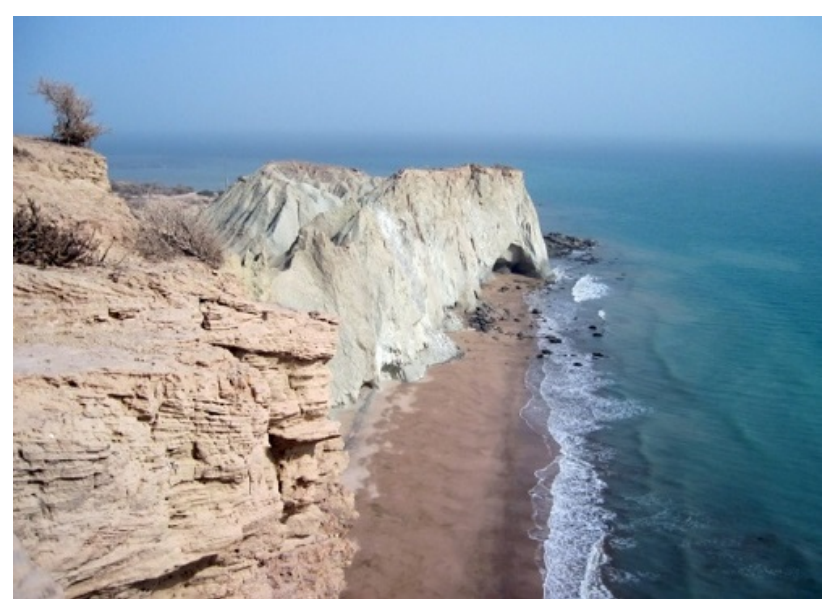

Figure 6. Precipice cliffs and rocks of eastern south of Hormoz (Aghajari formation has creamy colour and Mishan formation is green in farther areas).

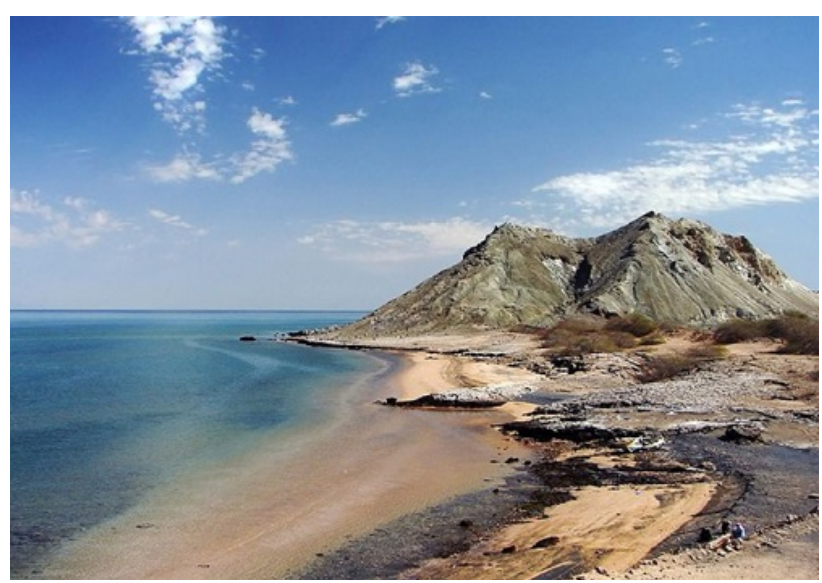

Figure 7. A nice view of southern seashores of Hormoz Island. 

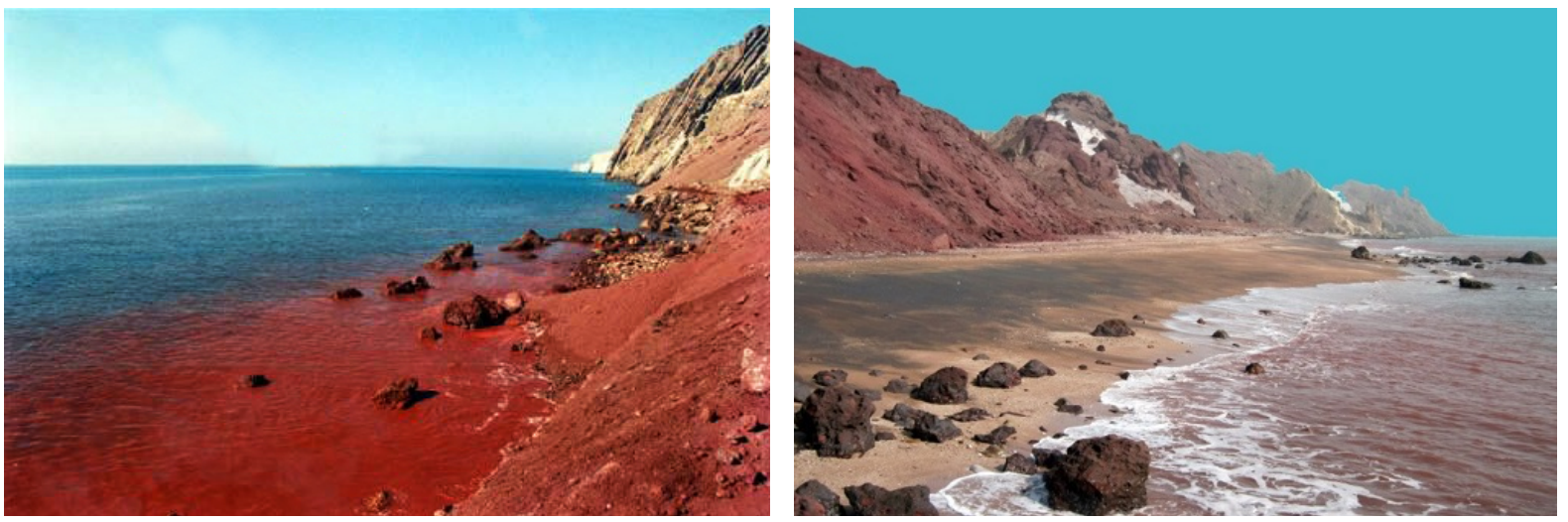

Figure 8. Red seashore around Hormoz ochre/red soil mine.

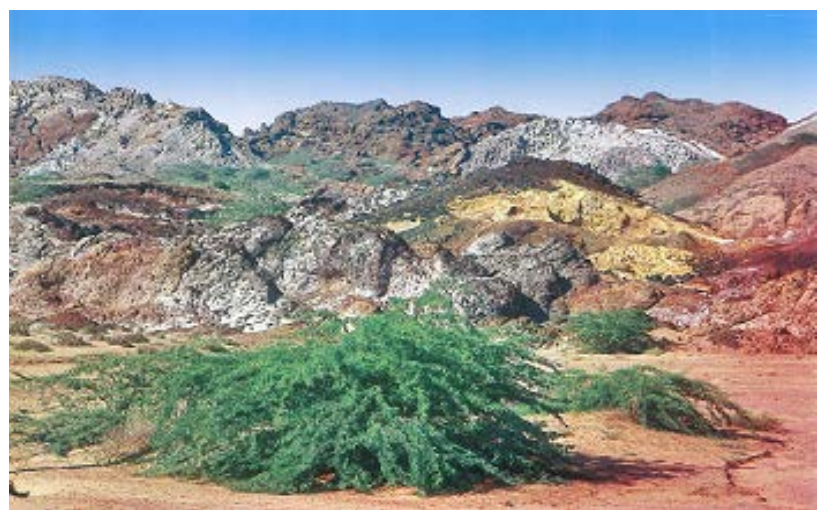

Figure 9. Colourful mountainous seashores of Hormoz Island.

- Other parts of Hormoz beach is constituted from beautiful ripple mark covered with oligiste crystals which make this area shiny especially at the time of sunshine (Figure 10).

\subsection{Red Soil Mine (Ochre Mine)}

Currently, this mineral material has been seen in Persian Gulf area in salt domes and some Islands. Among various mines in this area, Hormoz ochre mine can be referred to which is the most significant one. This mine has a reservoir about 390,000 tons and is unique in terms of quality and application in industries all over the world (Figure 11). The soil of this mine has application in some industries such as cosmetics, paint and rust, colourful glasses, paper, enamel, ceramic, rubber, colouring construction materials, chemical fertilizer and... (Aqanabati, 2006) [12]. Some years ago the soil of this mine was exported to countries such as Britain, France, Portuguese, India, EAU, and Pakistan and so on, however, now the export of this mineral material is controlled and it is less exported.

This mineral material is seen in form of lens shape masses and has been created due to washing of ferrous rocks by penetrating waters and transfer of $\mathrm{feo}^{+3}$ to the earth. Hydration of ferrite rick leads to creation of different kinds of hydrated oxides like limonite and goethite (Moeinvaziri, 1996) [13] which have created yellow and red mountains (especially in Qeshm-Hormoz path).

Native habitants of this Island call the red soil of this area as "Gelak" and use it in different kinds of food as spice. One of these foods is "Suragh" delicious food which is prepared by soaking Sardine fish in Hormoz red soil and orange and is served with bread (Figure 12).

\subsection{The Diverse Minerals of Hormoz Island}

Mineralization processes in igneous rocks lead to creation of various beautiful minerals such as oligiste, pyroxene, amphibole, pyrite, quartz, etc. in tacks of igneous rocks. This unique diversity in rocks and minerals has 


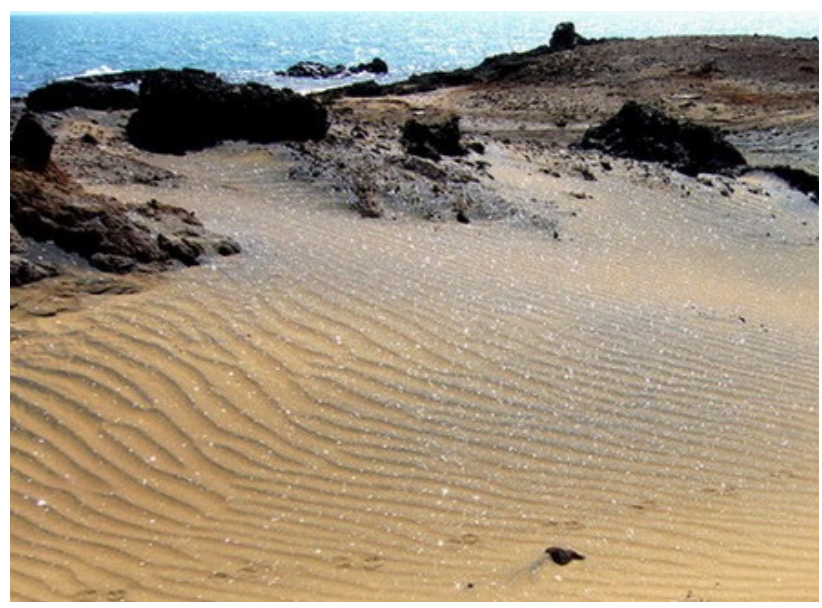

Figure 10. Ripple marks of seashore covered with oligiste mineral.

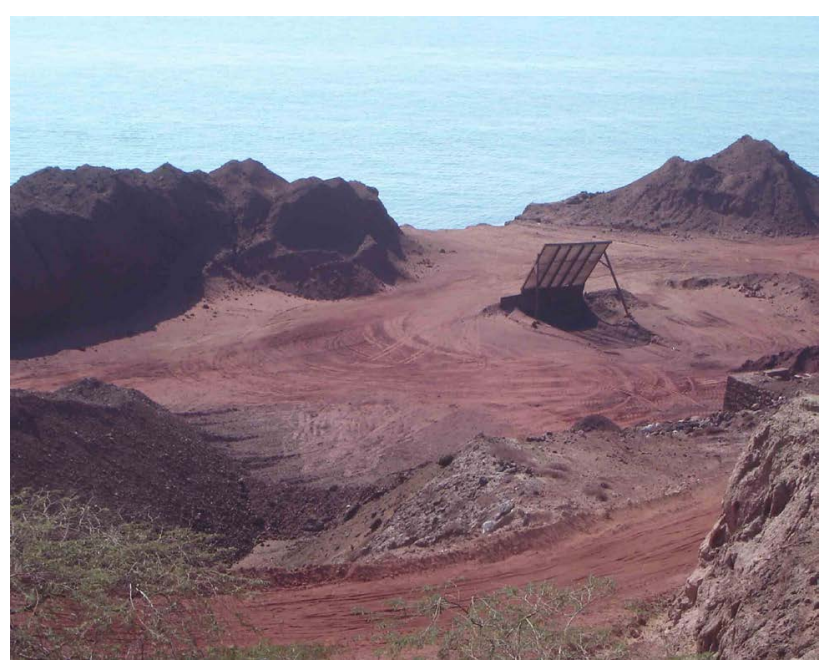

Figure 11. A layout of ochre mine of Hormoz Island.

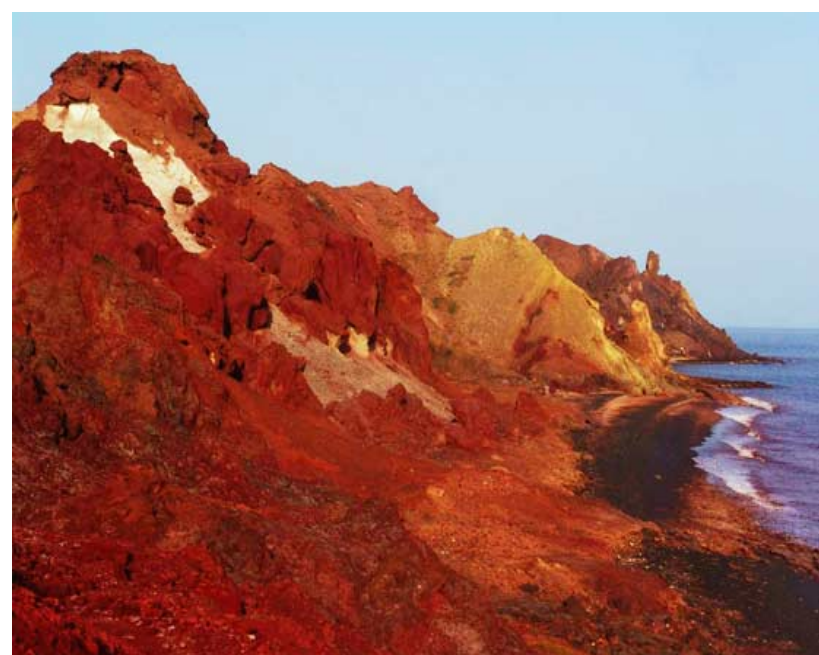

Figure 12. The area where native habitants of the region use its soil for food. 
created various colours in Hormoz Island and made it a treasure of minerals (Yazdi, 2013) [14].

Gypsum: These crystals can be found in some parts of Islands in form of rhombohedral. These crystals will turn to anhydrite white powder due to dehydration (Figure 13).

Pyroxene: In southern west of Hormoz Island, pyroxene has been formed between tracks of rhyolite masses. These crystals can be seen in $5 \mathrm{~cm}$ length along with oligiste and alpha quartz (Moeinvaziri, 1996) [13], (Figure 14).

Oligiste: High temperature oligiste crystals can be seen in form of bipyramid, hexagonal or in form of simple hexagonal pyramid, low temperature oligiste crystals can be seen in form of thin hexagonal aglet with rhombohedral surfaces in igneous rocks or in sedimentary rocks (shale and dolomite) (Figure 15).

Pyrite: This mineral material has been created in form of didodecahedral and octahedral in Hormoz igneous tuffs by fumerole. In addition to tuffs, pyrite automorph crystals can be seen in sedimentary rocks (Figure 16).

Apatite: Apatite crystals are frequent in ferrous riolite breccia and due to high frequency of these crystals, even they can be thought as a source for rare earth elements (Figure 17).

Dolomite: Dolomite is seen in form of big and automorph crystals in form of grayish and white rhombohedral and pinacoidal in sediments. Small and automorph crystals can be seen in some cavities (Figure 18).

Quartz: It is seen in form of hexagonal pyramids with rhombohedral surface.

\subsection{Salt Diverse Structure in Hormoz Island}

Since Hormoz Island is a salt dome, considerable structures of various salt forms can be seen in central parts of Island (Figure 19).

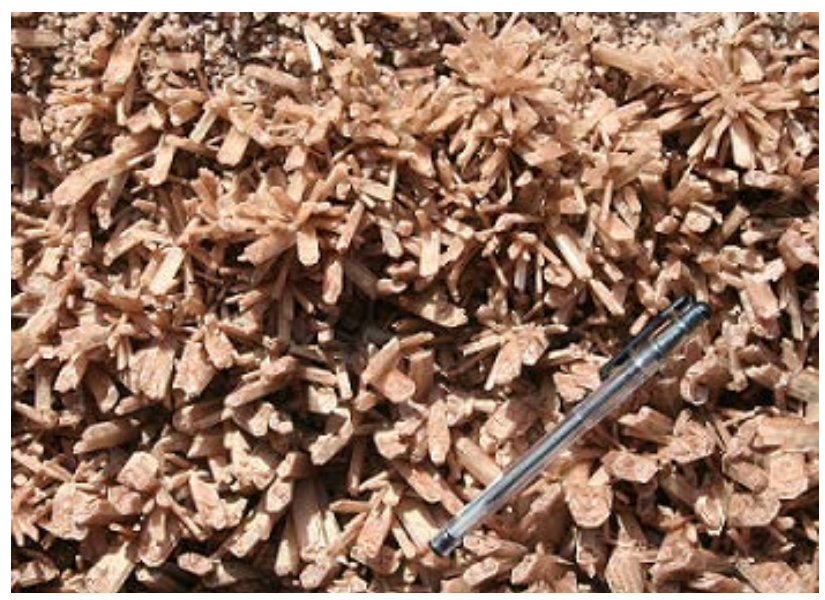

Figure 13. Gypsum beautiful crystals.

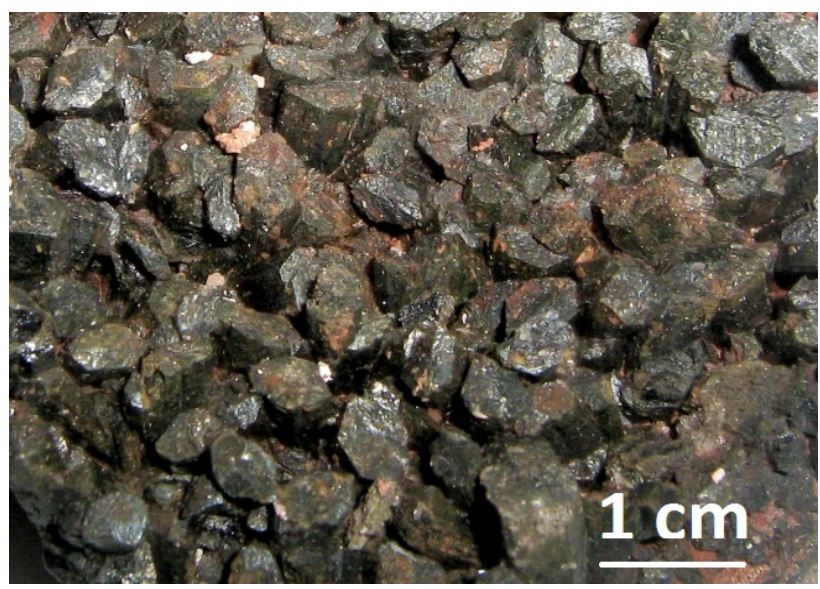

Figure 14. Pyroxene crystals of Hormoz Island. 


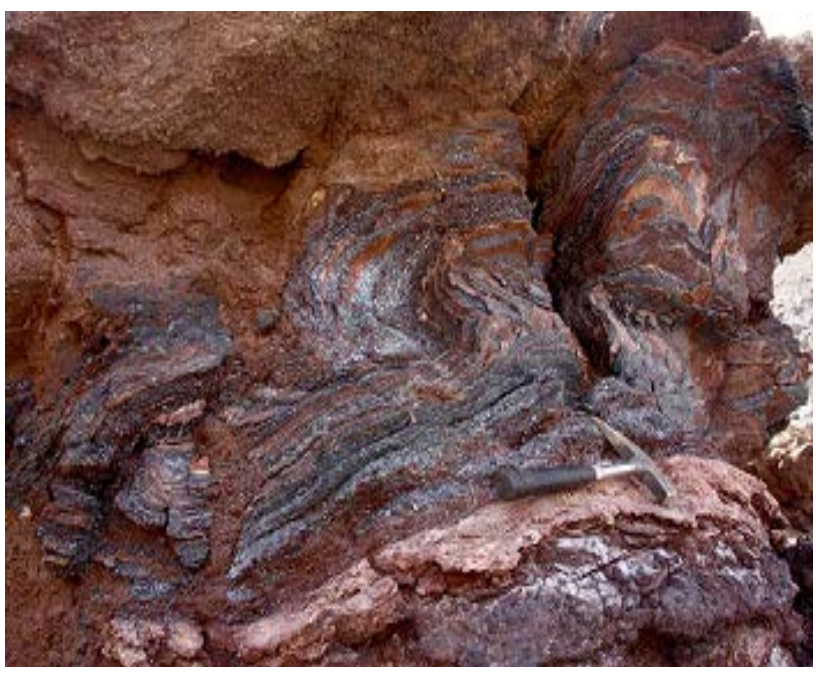

Figure 15. Wrinkled layers containing oligiste.

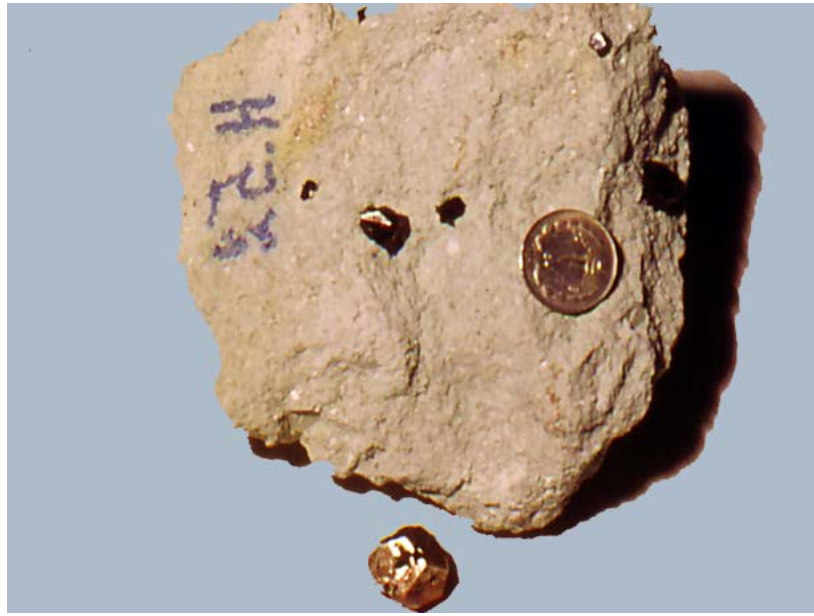

Figure 16. Pyrite crystals.

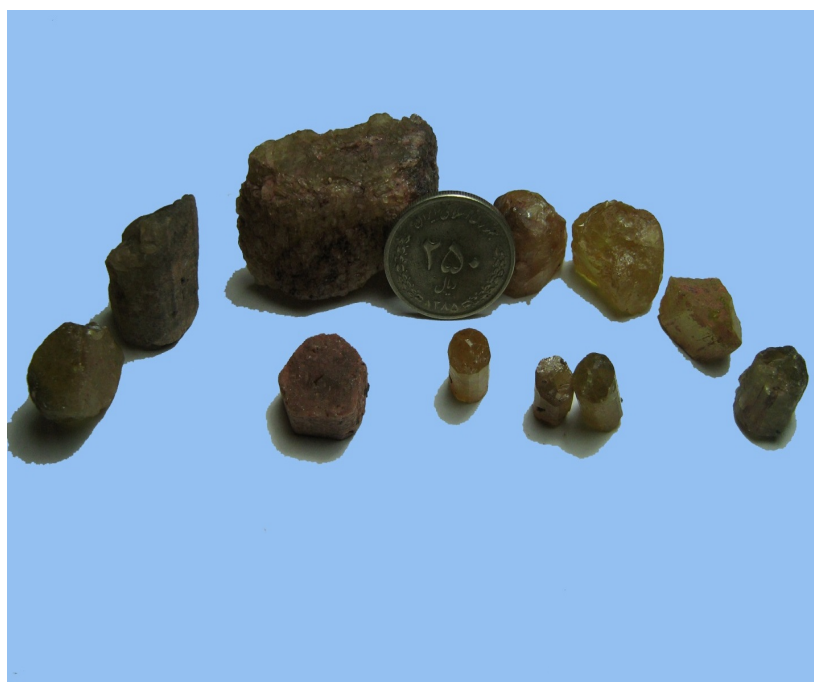

Figure 17. A sample Apatite in Hormoz Island. 


\subsection{Colourful Soils of Hormoz Island}

One of the amazing and wonderful geological phenomena of Iran is colourful mountains of Hormoz Island which have created landscape attractions of universe (Figure 20). It is an Island which is natural for geologists and an original scene for artists. What distinguishes Hormoz from other Islands of Persian Gulf is its colourful rainbow soil which has been formed due to diverse rocks and minerals. Thus, most artists design various shapes or carpets with this colourful soil which is unique and outstanding (Figure 21).

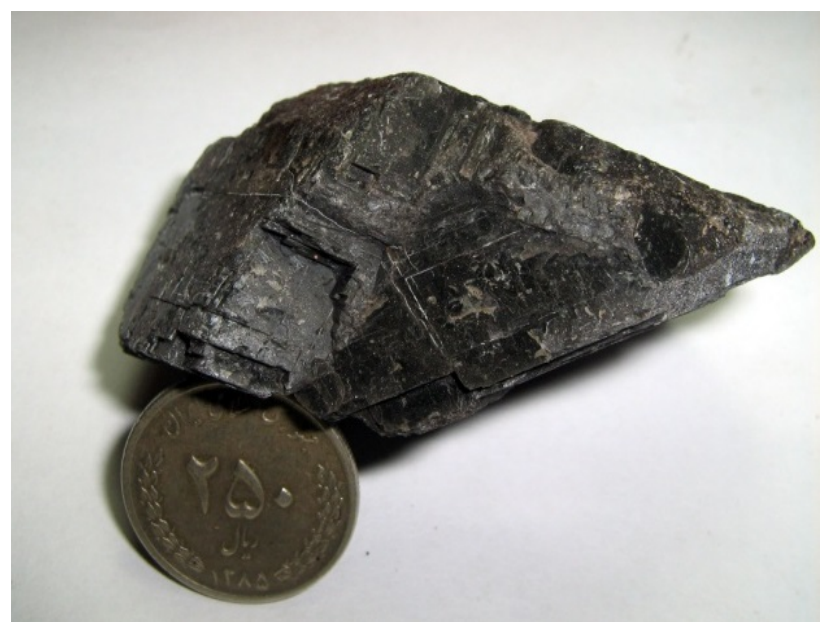

Figure 18. A sample Dolomite in Hormoz Island.
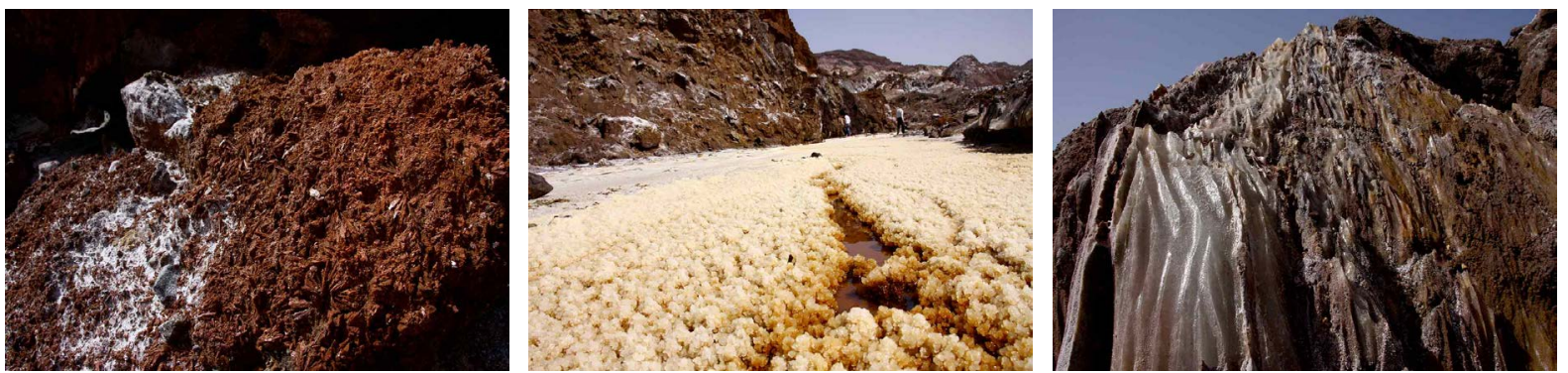

Figure 19. Diverse samples of solved salts and gypsum in Hormoz Island.

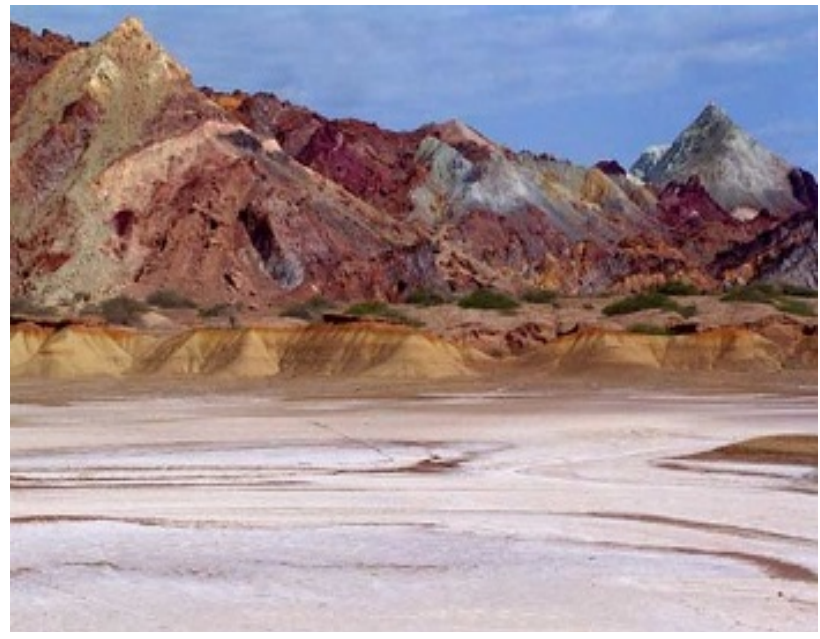

Figure 20. A view of unique diversity of coloured mountains of Hormoz. 


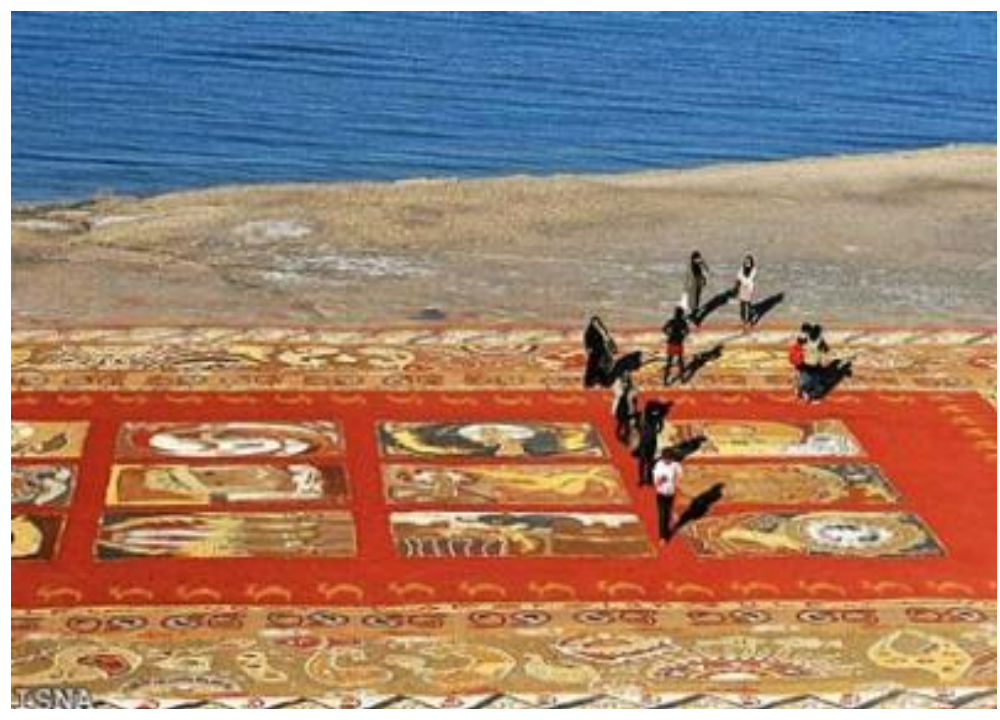

Figure 21. Carpets made of coloured soils of Hormoz.

\section{Conclusion}

What was mentioned in this paper indicates that considering the global significance of geotourism industry, Hormoz Island which is one of the most beautiful and important salt domes of universe, has high potential for geotourism development. Diversity in geological perspectives and numerous minerals of Hormoz Island, which made it a natural museum for fonder of geology, is a strong potential for making this region be one of the world geotourism poles and a proper area for researchers and scholars. In this way, researchers are able to take proper actions for scientific development of geotourism in this area with stronger foundations obtained from research finding and transfer scientific grounds of phenomenon and geo-sites to visitors. In this condition, geoconservation (conservation of geological phenomena) has been properly performed by tourists. Moreover, geotourism finds its real meaning besides economic development, thus, Hormoz Island can be a good pattern for achieving the above objectives.

\section{References}

[1] Bayati Khatibi, M., Shahabi, H. and Qaderi Zadeh, H. (2010) Geotourism: A New Approach in Utilization of Geomorphologic Attractions. Journal of Geographical Space, 29, 27-50.

[2] Papeli Yazdi, M.H. and Saghaei, M. (2011) Tourism, Nature \& Concepts. 6th Edition, Samt Publication, Tehran, 6.

[3] Servati, M.R. and Qasemi, A. (2008) Geotourism Strategies in Fars. Journal of Geographical Space, 2, 6.

[4] Yazdi, A. (2012) A Study of Iran's Lut Desert: Geomorphological and Geotourism Attractions. Proceedings of Annual International Conference on Geological \& Earth Sciences (GEOS2012), Singapore, 3-4 December 2012, 35-41.

[5] Newsome, D. and Dowling, R.K. (2006) The Scope and Nature of Geotourism. In: Dowling, R.K. and Newsome, D., Eds., Geotourism, Chapter One, Elsevier, Oxford, 3-25.

[6] Gates, A.E. (2006) Geotourism: A Perspective from the USA. In: Dowling, R.K. and Newsome, D., Eds., Geotourism, Chapter Nine, Elsevier, Oxford, 157-179. http://dx.doi.org/10.1016/B978-0-7506-6215-4.50017-8

[7] Dowling, R.K. and Newsome, D. (2006) Geotourism's Issues and Challenges, Geotourism, Chapter Thirteen, Elsevier, Oxford, 242-254.

[8] Amrikazemi, A. (2009) Atlas of Geopark \& Geotourism Resources of Iran. Geological Survey of Iran Publication, Tehran, 22-23.

[9] Elyasi, J., Aminsobhani, E., Behzad, A., Moeinvaziri, H. and Meysami, A. (1975) Geology of Hormoz Island. Geological Survey of Iran Publication, Tehran, 1, 13.

[10] Stocklin, J. (1972) Lexique Stratigraphique International. Vol. 3, Geological Survey of Iran Publication, Tehran, 6, 15.

[11] Waltham, T. (2008) Salt Terrains of Iran. Geology Today, 24, 188-194. http://dx.doi.org/10.1111/j.1365-2451.2008.00686.x 
[12] Aqanabati, S.A. (2006) Geology and Mineral Potential of Hormozgan Province. Journal of Development of Geology Training, 12, 4-11.

[13] Moeinvaziri, H. (1996) An Introduction of Magmatism in Iran. University of Tarbiat Moalem Publication, Tehran, 440.

[14] Yazdi, A., Emami, M.H. and Jafari, H.R. (2013) IRAN, the Center of Geotourism Potentials. Journal of Basic and Applied Scientific Research, 3, 458-465. 
Scientific Research Publishing (SCIRP) is one of the largest Open Access journal publishers. It is currently publishing more than 200 open access, online, peer-reviewed journals covering a wide range of academic disciplines. SCIRP serves the worldwide academic communities and contributes to the progress and application of science with its publication.

Other selected journals from SCIRP are listed as below. Submit your manuscript to us via either submit@scirp.org or Online Submission Portal.
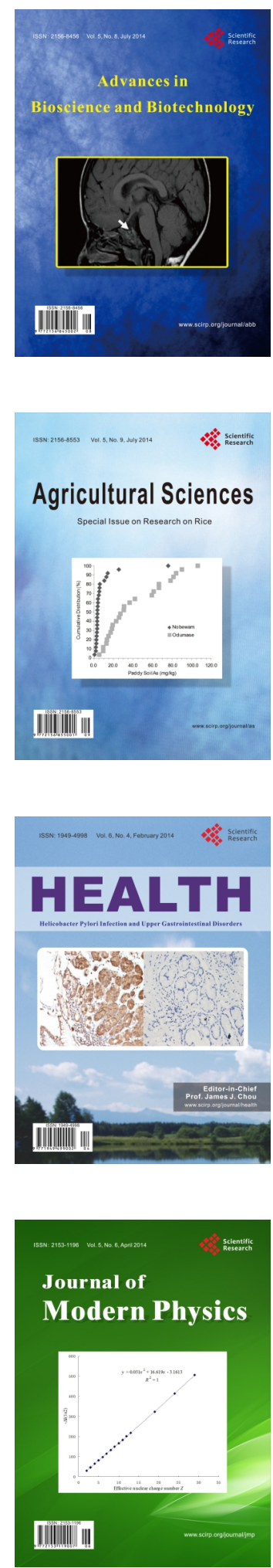
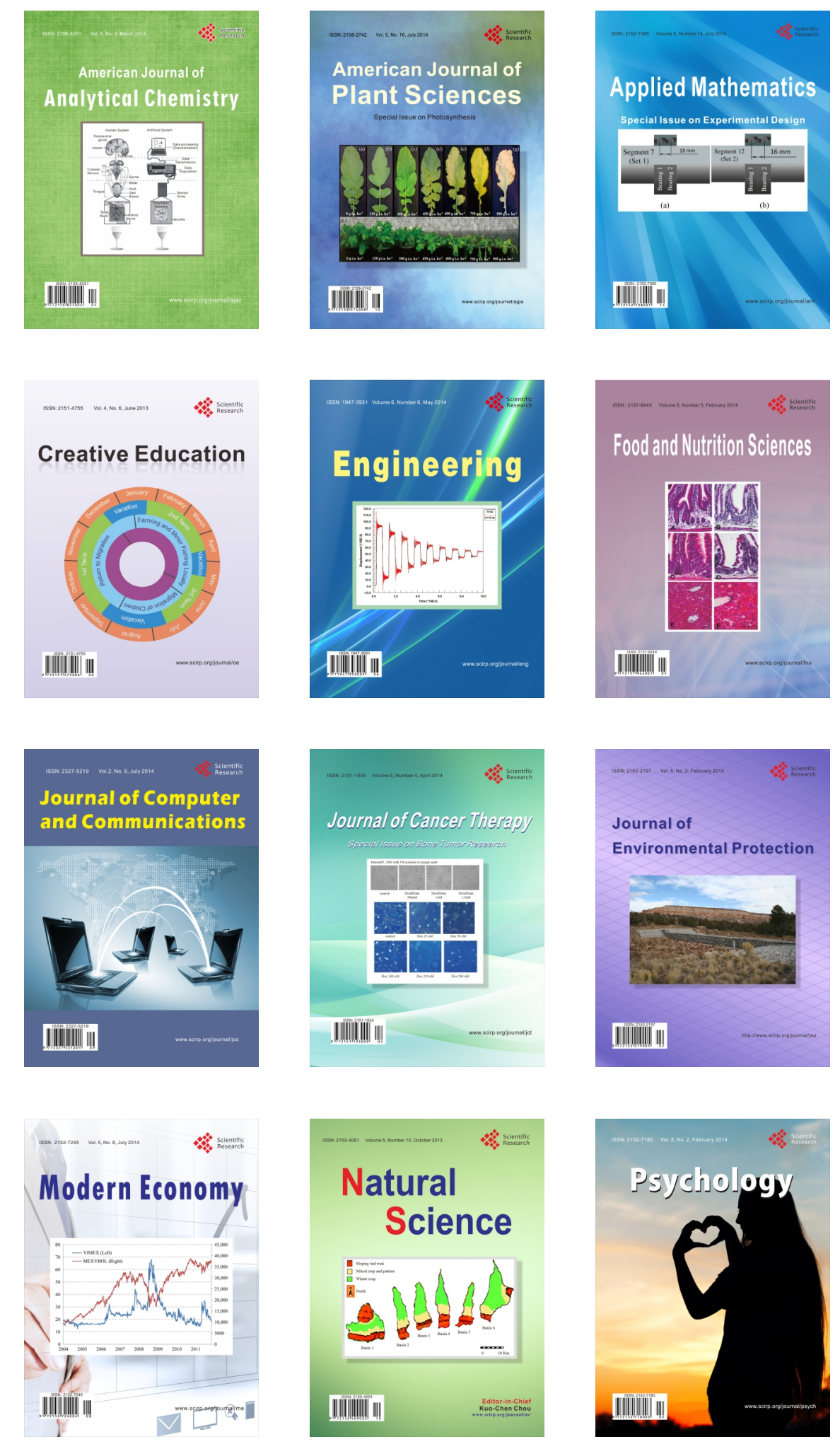